\title{
Paleomagnetic dating of tectonically influenced Plio-Quaternary fan-system deposits from the Apennines (Italy)
}

\author{
Michele Saroli ${ }^{1,2}$, Marco Moro ${ }^{2}$, Fabio Florindo ${ }^{2}$, Michele Lancia ${ }^{1}$, \\ Pontus C. Lurcock ${ }^{2, \star}$, Jaume Dinarès-Turell ${ }^{2}$ \\ ${ }^{1}$ Università degli Studi di Cassino e del Lazio Meridionale, Cassino, Italy \\ ${ }^{2}$ Istituto Nazionale di Geofisica e Vulcanologia, Rome, Italy
}

\section{Article history}

Received January 22, 2015; accepted January 29, 2015.

Subject classification:

Geochronology, Sediments, Stratigraphy, Rock magnetism, Paleomagnetism, Quaternary breccias, Central Italy.

\begin{abstract}
The Roveto Valley is a narrow, elongated, NW-trending depression filled with continental Plio-Quaternary deposits that outcrop at different topographic elevations. A morpho-lithostratigraphic succession of the continental deposits has been defined in order to reconstruct the geological Quaternary evolution of the area. These deposits do not contain materials suitable for biostratigraphic dating; therefore, in order to determine their chronology, three different units were sampled for magnetostratigraphic investigations. Paleomagnetic results demonstrated that standard demagnetization techniques are effective in removing secondary remanence components and in isolating the characteristic remanent magnetization, allowing us to determine, for each cycle, whether it was deposited before or after the Brunhes-Matuyama geomagnetic reversal at $781 \mathrm{ka}$. Preliminary rock magnetic analyses indicated that magnetite is the main magnetic carrier and that hematite, which gives the pink colour to the matrix, is in the superparamagnetic grain-size range and thus does not retain any paleomagnetic remanence.
\end{abstract}

\section{Introduction}

The Roveto Valley area is part of a segment of the Apennine mountain range, which was intensively deformed by Neogene-Quaternary compressional and extensional tectonics [Saroli et al. 2003 and references therein, Saroli and Moro 2012]. This sector of the chain was mostly formed during the Neogene, in the context of the eastward piggy-back propagation of the Apennines thrust system. Geomorphologically, the Roveto Valley is a narrow, elongated, NW-trending morphological depression, bounded by some of the most significant regional tectonic features of the whole Apennine range, such as the Simbruini - Ernici Mts. basal (leading) thrust and the Val Roveto - Atina - Caserta Line (Figure 1).

Continental Plio-Quaternary alluvial-fan deposits (alluvial-fan conglomerate and sands) are clear geomorphic markers which outcrop at different topo-

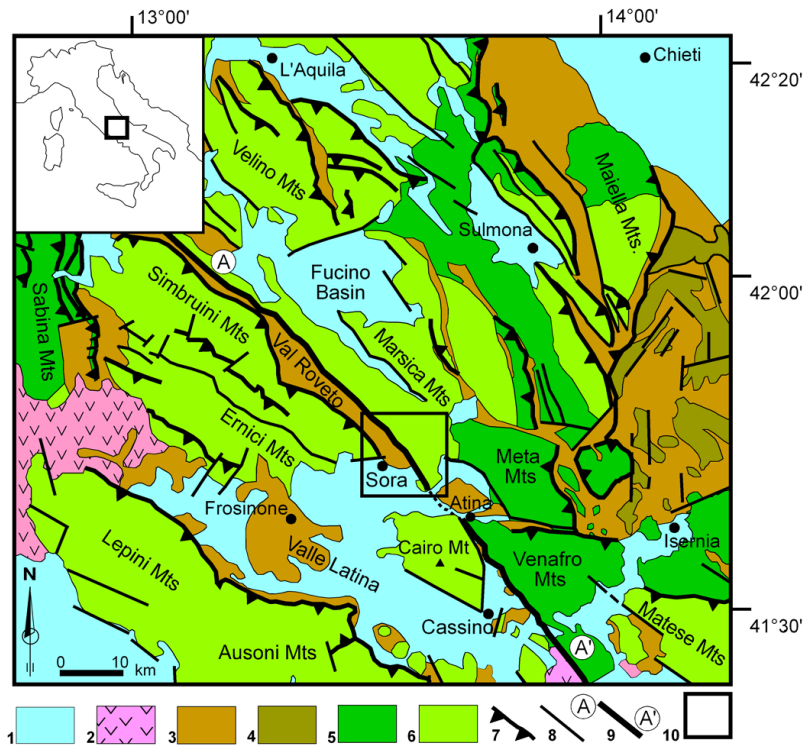

Figure 1. Simplified geological map of the central Apennines. Legend: 1) marine and continental clastic deposits (Pliocene-Quaternary); 2) volcanic deposits (Pleistocene); 3) synorogenic hemipelagic and turbiditic sequences (Tortonian-Pliocene); 4) Molise-Sannio pelagic units (Cretaceous-Miocene); 5) slope and pelagic deposits (Lias-Miocene); 6) carbonate platform deposits (Trias-Miocene); 7) main thrust; 8) main normal and/or strike-slip fault; 9) Val Roveto - Atina Line; 10) location of the studied area.

graphic elevations (Figure 2a, 2b). These sedimentary bodies, with their corresponding erosional and/or depositional surfaces (Figure 2c, 2d, 2e), constitute a morpho-lithostratigraphic succession (Figure 2b) [Bosi et al. 2003, Messina et al. 2003] linked to the local tectonosedimentary setting [Saroli et al. 2003, Saroli and Moro 2012]. As is often the case with central Apennine Pleistocene continental deposits, these sediments do not contain material suitable for biostratigraphic dating. Therefore, to determine the chronology of the Val Roveto continental deposits, three different units of the 


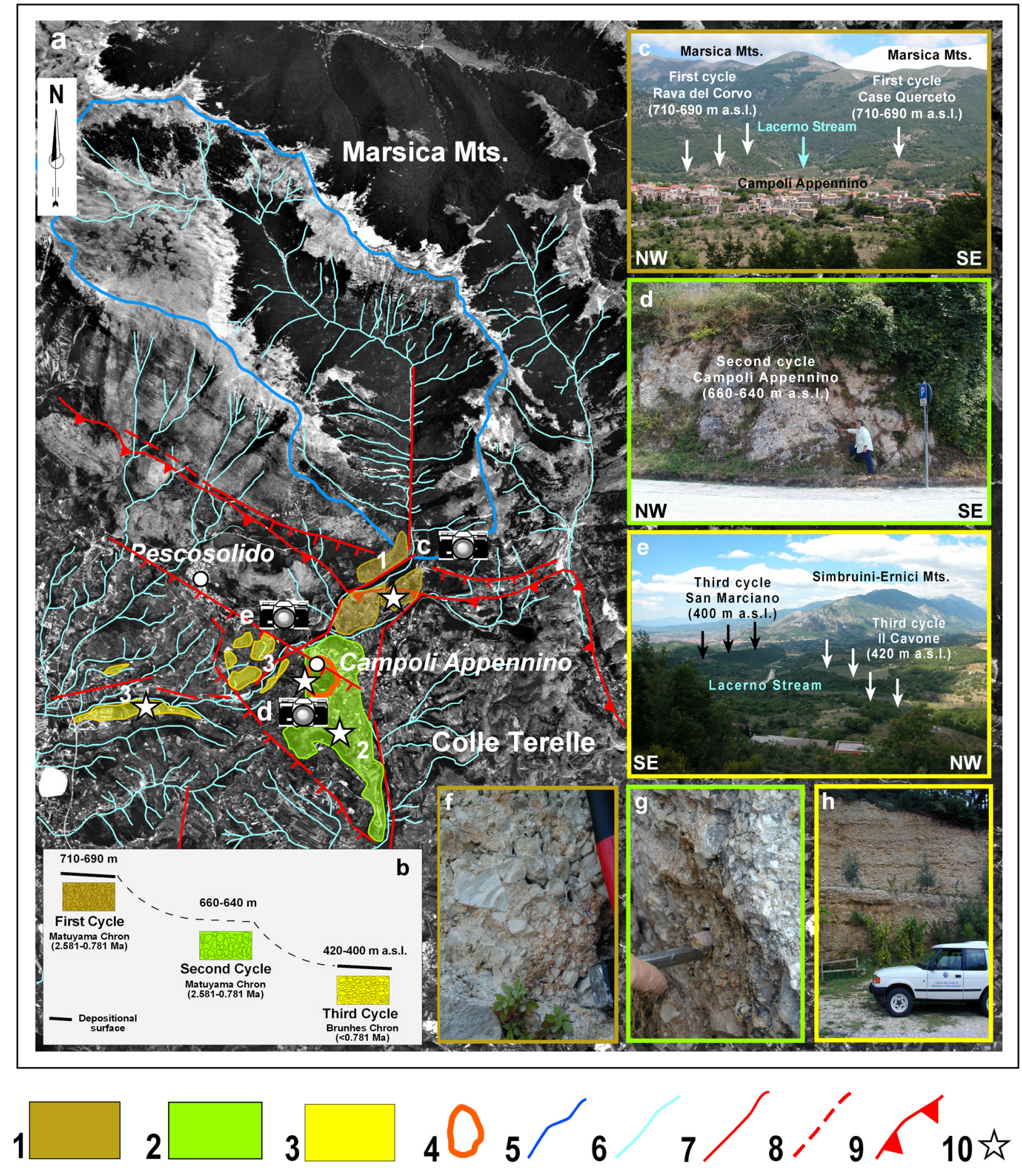

Figure 2. a) Morpho-lithostratigraphic analysis by photogeological interpretation and field surveys. Legend: 1) alluvial-fan first cycle (Il Cavone, Rava del Corvo, Case Querceto, 710-690 m a.s.1.); 2) alluvial-fan second cycle (Campoli Appennino, 660-640 m a.s.l.); 3) alluvial-fan third cycle (Il Cavone, San Marciano, 420-400 m a.s.1.); 4) doline; 5) Lacerno stream watershed; 6) drainage; 7) fault; 8) inferred fault; 9) thrust; 10) sampling site. b) Quaternary stratigraphic units of the Campoli Appennino area; c) landscape view of the alluvial-fan first cycle; d) outcrop of the alluvial-fan second cycle; e) landscape view of the alluvial-fan third cycle; f) talus from the first cycle unit; g) rounded breccia from the second cycle unit; h) gravel levels from the third cycle unit.

recognized morpho-lithostratigraphic succession were sampled for magnetostratigraphic investigation (Figure $2 \mathrm{a}, 2 \mathrm{f}, 2 \mathrm{~g}, 2 \mathrm{~h})$. In this study, a better assessment of the geological Quaternary evolution of the Campoli Appennino sector has been achieved by the integration of paleomagnetic data with stratigraphic, morphological, and tectonic features [Messina et al. 2001].
2. Electron microprobe and magnetostratigraphic investigations

Cycles 1, 2, and 3 of the identified morpho-lithostratigraphic succession were sampled and 4 thin sections were analyzed with an electron microprobe model Cameca SX-50 equipped with 5 WDS spectrometers and an energy dispersive spectrometer (EDS). Results 


\begin{tabular}{|c|c|c|c|c|c|c|c|c|c|c|}
\hline & \multirow{2}{*}{\multicolumn{2}{|c|}{$\begin{array}{c}\text { Point } 6 \\
\text { magnetite }\end{array}$}} & \multirow{2}{*}{\multicolumn{2}{|c|}{$\begin{array}{l}\text { Point } 8 \\
\text { recent cement }\end{array}$}} & \multirow{2}{*}{\multicolumn{2}{|c|}{$\begin{array}{c}\text { Point } 9 \\
\text { primary cement }\end{array}$}} & \multirow{2}{*}{\multicolumn{2}{|c|}{$\begin{array}{c}\text { Point } 10 \\
\text { calcium carbonate }\end{array}$}} & \multirow{2}{*}{\multicolumn{2}{|c|}{$\begin{array}{c}\text { Point } 14 \\
\text { titanomagnetite }\end{array}$}} \\
\hline & & & & & & & & & & \\
\hline & Conc. & Cations & Conc. & Cations & Conc. & Cations & Conc. & Cations & Conc. & Cations \\
\hline $\mathrm{SiO}_{2}$ & 0.043 & 0.012 & 47.087 & 7.397 & 5.432 & 1.240 & 0.016 & 0.006 & 0.043 & 0.012 \\
\hline $\mathrm{TiO}_{2}$ & 8.545 & 1.822 & 0.858 & 0.101 & 39.360 & 6.758 & 0.000 & 0.000 & 5.465 & 1.143 \\
\hline $\mathrm{Al}_{2} \mathrm{O}_{3}$ & 2.014 & 0.673 & 28.713 & 5.316 & 3.036 & 0.817 & 0.007 & 0.003 & 3.482 & 1.142 \\
\hline $\mathrm{Cr}_{2} \mathrm{O}_{3}$ & 0.118 & 0.027 & 0.000 & 0.000 & 0.139 & 0.025 & 0.000 & 0.000 & 0.049 & 0.011 \\
\hline $\mathrm{MgO}$ & 1.382 & 0.584 & 1.625 & 0.381 & 0.368 & 0.125 & 0.010 & 0.006 & 1.342 & 0.556 \\
\hline $\mathrm{CaO}$ & 0.542 & 0.165 & 1.179 & 0.198 & 25.578 & 6.257 & 58.654 & 23.970 & 0.243 & 0.073 \\
\hline $\mathrm{MnO}$ & 0.487 & 0.117 & 0.028 & 0.004 & 0.013 & 0.002 & 0.000 & 0.000 & 1.047 & 0.247 \\
\hline $\mathrm{FeO}$ & 77.611 & 18.408 & 2.252 & 0.296 & 1.411 & 0.269 & 0.018 & 0.006 & 81.960 & 19.065 \\
\hline $\mathrm{NiO}$ & 0.023 & 0.005 & 0.002 & 0.000 & 0.000 & 0.000 & 0.000 & 0.000 & 0.056 & 0.013 \\
\hline $\mathrm{Na}_{2} \mathrm{O}$ & 0.000 & 0.000 & 0.089 & 0.027 & 0.020 & 0.012 & 0.000 & 0.000 & 0.024 & 0.013 \\
\hline $\mathrm{K}_{2} \mathrm{O}$ & 0.011 & 0.004 & 1.371 & 0.275 & 0.541 & 0.158 & 0.008 & 0.004 & 0.012 & 0.004 \\
\hline Total: & 90.776 & 21.817 & 83.204 & 13.995 & 75.905 & 15.663 & 58.713 & 23.995 & 93.723 & 22.279 \\
\hline
\end{tabular}

Table 1. Element concentrations obtained by EDS microprobe analysis of thin sections. Locations of points 6, 10, and 14 on thin sections are shown in Figure 3.

are shown in Table 1. Preliminary electron microscope investigations of polished sections indicate that magnetite, ilmenite, titanomagnetite, and garnet are distributed within the pink-coloured matrix (Figure 3). The primary cement is mainly composed of calcium carbonate (Table 1, Point 9) and shows a clear difference in mineralogical composition compared to the more recent weathering cement (Table 1, Point 8).

For the paleomagnetic analysis, about 80 cores were drilled from the three cycles of the morpho-lithostratigraphic succession. An ASC 280E gasoline-powered portable drill was used with a water-cooled diamond

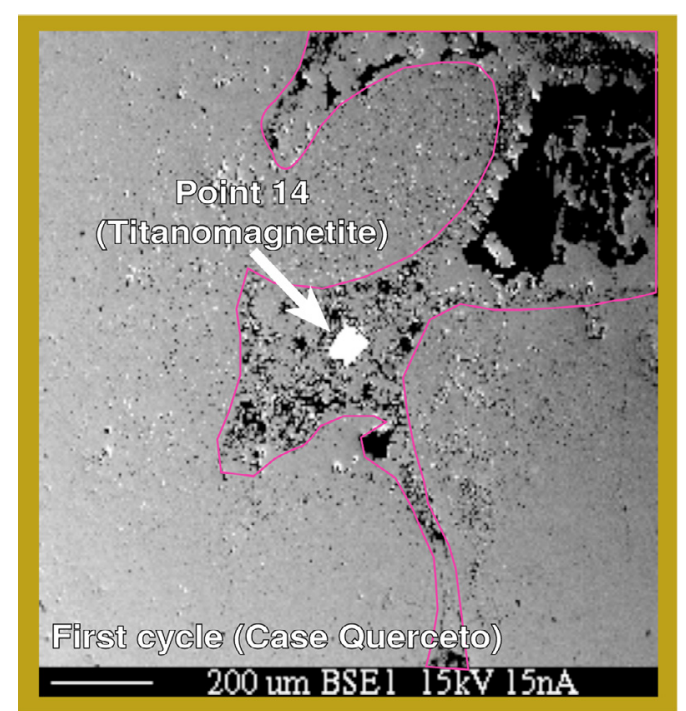

bit, and the cores were oriented in situ using a magnetic compass.

The magnetic measurements were carried out at the paleomagnetic laboratory of the Istituto Nazionale di Geofisica e Vulcanologia in Rome. All the specimens were demagnetized in 11-20 steps and the remaining natural remanent magnetization (NRM) was measured after each step with a $4.5 \mathrm{~cm}$ access pass-through $2 \mathrm{G}$ cryogenic magnetometer housed in a Lodestar Magnetics shielded room. For each site, $50 \%$ of the samples were stepwise alternating-field (AF) demagnetized and the remaining samples were subjected to stepwise ther-

Figure 3. Electron micrographs of thin sections. Mineral identifications are given for selected points; see Table 1 for detailed composition data. 
mal demagnetization, from room temperature up to $650^{\circ} \mathrm{C}$.

The results indicated that thermal and AF demagnetization are equally effective in removing secondary remanence components and in isolating the characteristic remanent magnetization. Preliminary magnetic coercivity and thermomagnetic analyses indicated that magnetite is the main magnetic carrier. We therefore suggest that the hematite responsible for the pink colour of the matrix is in the paramagnetic or superparamagnetic grain-size range $(<28 \mathrm{~nm}$ as determined by Banerjee [1971]) and thus does not retain any paleomagnetic remanence.

Demagnetization data were plotted as demagnetization-intensity graphs and Zijderveld [1967] plots. NRM directions were calculated by principal component analysis [Kirschvink 1980] and plotted on equalarea projections. Selected results are shown in Figure 4. The site mean directions are quite well-defined, and are better grouped in the geographic reference frame before tilt correction. This grouping suggests that these units were deposited onto an inclined surface, along the
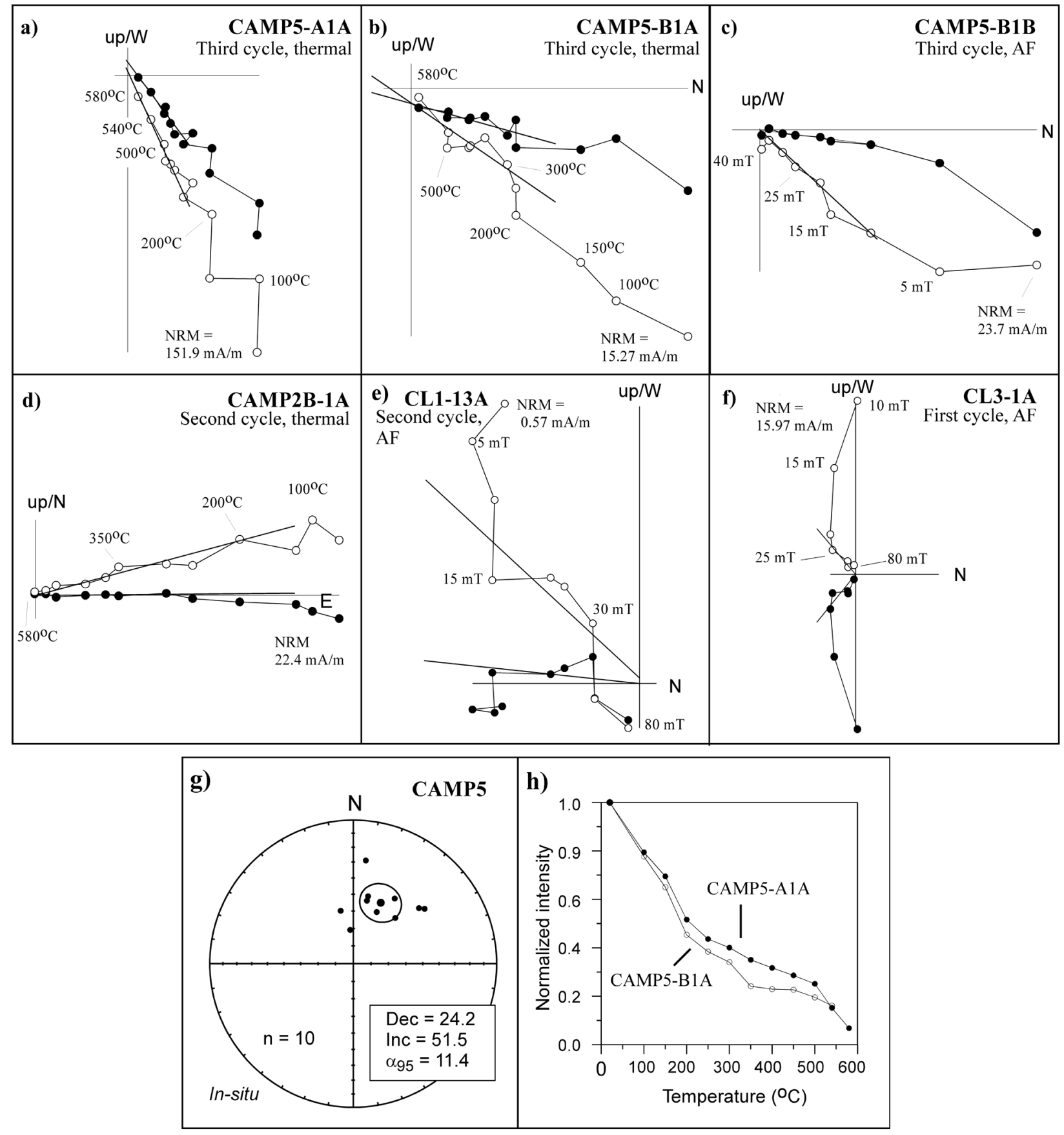

Figure 4. Selected paleomagnetic results. Upper panel, a)-f): Zijderveld plots showing demagnetization behaviour under AF and thermal treatment for samples from each of the three cycles. Best-fit PCA directions are shown as overlaid straight line segments. Lower panel: g) third-cycle NRM directions plotted on an equal-area projection; h) demagnetization-intensity plot for two third-cycle samples. 
slope of calcareous reliefs. The in-situ mean directions are close to the directions of a recent reverse geocentric axial dipole field recognized in the central Apennines. The analysis of the two sites belonging to the first and the second depositional cycles (Rava del Corvo - Case Querceto and Campoli Appennino, respectively) gives a reverse magnetic polarity. The third site, belonging to the third depositional cycle (San Marciano), has a normal polarity. We surmise that the latter unit has been deposited during the Brunhes Normal Chron, and is therefore younger than $781 \mathrm{ka}$ [Gradstein et al. 2012]. On the basis of the available tectono-stratigraphic constraints [Saroli et al. 2003 and references therein], we infer that the deposition of the first two units occurred during the reverse Matuyama Chron, probably between 2.581 and $0.781 \mathrm{Ma}$.

\section{Conclusions}

The integration of morpho-lithostratigraphic data and paleomagnetic measurements allowed us to date the samples of the first and second cycle to the early Pleistocene (Matuyama Reverse Chron). The samples of the third cycle, the most recent in the morpho-lithostratigraphic succession, have a normal polarity (Brunhes Normal Chron) and must therefore be younger than $781 \mathrm{ka}$. Paleomagnetic results demonstrated that standard demagnetization techniques are effective in removing secondary remanence components and in isolating the characteristic remanent magnetization in these alluvial fan deposits. These methods allowed us to determine, for each cycle, whether it was deposited before or after the Brunhes-Matuyama paleomagnetic boundary at $781 \mathrm{ka}$. Information from paleomagnetic analyses, integrated with stratigraphic, morphological and tectonic features, could in the future be used to define a more complete geological and tectonic Quaternary evolution of the Campoli Appennino sector.

\section{References}

Banerjee, S.K. (1971). New grain size limits for palaeomagnetic stability in haematite, Nature, 232 (27), 15-16.

Bosi, C., P. Messina and M. Moro (2003). Nuovi procedimenti cartografici per il Quaternario continentale: l'esempio della Carta geologica dell'alta Valle dell'Aterno, Il Quaternario, Italian Journal of Quaternary Sciences, 16 (1), 109-120.

Gradstein, F.M., G. Ogg and M. Schmitz, eds. (2012). The Geologic Time Scale 2012 2-Volume Set, Elsevier, Amsterdam.

Kirschvink, J.L. (1980). The least-squares line and plane and the analysis of palaeomagnetic data, Geophysical Journal International, 62 (3), 699-718.
Messina, P., M. Moro and F. Speranza (2001). Primi risultati di stratigrafia magnetica su alcune formazioni continentali dell'alta valle dell'Aterno (Italia centrale), Il Quaternario, Italian Journal of Quaternary Sciences, 14 (2),167-172.

Messina, P., C. Bosi and M. Moro (2003). Sedimenti e forme quaternari nell'alta valle dell'Aterno (L'Aquila), Il Quaternario, Italian Journal of Quaternary Sciences, 16 (2), 231-239.

Saroli, M., A. Biasini, G.P. Cavinato and E. Di Luzio (2003). Geological Setting of the Southern Sector of the Roveto Valley (Central Apennines, Italy), Bollettino della Società Geologica Italiana, 122, 467-481.

Saroli, M., and M. Moro (2012). Campoli Appennino. Field-trip guidebook, 16th Joint Geomorphological Meeting (Rome, Italy, July 1-5, 2012), edited by AIGeo.

Zijderveld, J.D.A. (1967). A.C. demagnetization of rocks: analysis of results, In: D.W. Collinson, K.M. Creer and S.K. Runcorn (eds.), Methods in Palaeomagnetism, Amsterdam, Elsevier, 254-286.

\footnotetext{
*Corresponding author: Pontus C. Lurcock, Istituto Nazionale di Geofisica e Vulcanologia, Rome, Italy; email: pont@talvi.net.

C 2015 by the Istituto Nazionale di Geofisica e Vulcanologia. All rights reserved.
} 